\title{
Do large volume spacer devices reduce the systemic effects of high dose inhaled corticosteroids?
}

\author{
Peter H Brown, Gillian Blundell, Andrew P Greening, Graham K Crompton
}

\begin{abstract}
When used in high doses, inhaled corticosteroids may cause suppression of the hypothalamo-pituitary-adrenal axis. The influence of the mode of drug inhalation on the degree of this suppression is not clear. Hypothalamo-pituitaryadrenal function was assessed by measurement of $0900 \mathrm{~h}$ serum cortisol concentrations, a short tetracosactrin test, and 24 hour urine free cortisol excretion in 48 adults with asthma taking 1500-2500 $\mu \mathrm{g}$ beclomethasone dipropionate daily via a metered dose aerosol. Twelve patients had hypothalamopituitary-adrenal suppression, as judged by subnormal results from at least two of the three tests or (in one patient) by an abnormal insulin stress test response. These patients then changed to inhaling the same dose of beclomethasone dipropionate through a $750 \mathrm{ml}$ spacer device (Volumatic). The endocrine tests were repeated from nine days to eight weeks later in 10 patients. Comparison with initial values showed that adding the spacing device caused an increase in the median $0900 \mathrm{~h}$ cortisol concentration from $126 \mathrm{nmol} / 1$ to $398 \mathrm{nmol} / \mathrm{l}$, in the post-tetracosactrin cortisol concentration from $402 \mathrm{nmol} / 1$ to $613 \mathrm{nmol} / 1$ and in 24 hour urine free cortisol excretion from $54 \mathrm{nmol}$ to $84 \mathrm{nmol}$. The rise in serum cortisol concentration in response to tetracosactrin did not change. Evidence of persisting hypothalamopituitary-adrenal axis suppression was present in only four of the 10 patients; the most pronounced improvements in function tended to occur in those who had never required long term oral corticosteroids. The results from this uncontrolled study suggest that asthmatic patients taking high dose beclomethasone dipropionate may minimise adverse effects by using a large volume spacer device.
\end{abstract}

Several studies have shown that the use of inhaled corticosteroids in high doses often improves the symptoms of patients with severe chronic asthma not well controlled by conventional doses of inhaled steroid (for example $\quad 400-800 \mu \mathrm{g}$ beclomethasone dipropionate daily). ${ }^{1-3}$ In patients who are dependent on long term oral corticosteroid increasing the dose of beclomethasone dipropionate to $1500-2000 \mu \mathrm{g}$ daily may allow reduction or withdrawal of prednisolone treatment. ${ }^{134}$ Treatment with beclomethasone dipropionate in doses of $2000 \mu \mathrm{g}$ daily, via a conventional metered dose inhaler, will cause substantial suppression of the hypothalamopituitary-adrenal axis function in some patients. ${ }^{5}$ Higher doses of inhaled corticosteroids are also associated with an increased incidence of oropharyngeal candidiasis, which can be reduced by the use of a large volume spacer device. ${ }^{6}$ It is not clear, however, whether large volume spacers increase or decrease the potential of inhaled corticosteroids to produce adverse systemic effects. ${ }^{78}$

From a survey of hypothalamo-pituitaryadrenal axis function in adults with asthma taking high dose beclomethasone dipropionate via a conventional metered dose inhaler, we identified a group of patients with suppressed function of this axis. This study reports the changes in hypothalamo-pituitary-adrenal function that occurred in these patients when they inhaled the same dose of beclomethasone dipropionate through a metered dose inhaler attached to a large volume spacer device.

\section{Methods}

Tests of hypothalamo-pituitary-adrenal axis function (measurement of $0900 \mathrm{~h}$ serum cortisol concentration and 24 hour urine free cortisol excretion and the short tetracosactrin test) were performed in 48 adults with asthma (27 of them male; age 16-71 years) who were taking 1500-2500 $\mu \mathrm{g}$ beclomethasone dipropionate daily but no regular oral or parenteral corticosteroids. These screening tests were carried out as part of a survey of hypothalamo-pituitary-adrenal function in adults with asthma inhaling high dose corticosteroids, details of which will be reported separately. In those who had required a recent short course of prednisolone the tests were carried out at least two weeks after its completion. Hypothalamo-pituitary-adrenal suppression was identified in 12 of the 48 patients; the previous corticosteroid treatment for these patients is shown in table 1 . Two of the patients (Nos 8 and 11) had required a short course of prednisolone in the two months before the investigation.

All patients could use a metered dose inhaler efficiently and had taken their morning dose of beclomethasone dipropionate between 0600 and $0800 \mathrm{~h}$. Venous blood sampling was performed at $0900 \mathrm{~h}$, imme- 
Table 1 Corticosteroid histories of asthmatic patients with subnormal hypothalamo-pituitary-adrenal axis function taking high dose beclomethasone dipropionate (BDP)

\begin{tabular}{|c|c|c|c|c|c|c|}
\hline $\begin{array}{l}\text { Patient } \\
\text { No }\end{array}$ & $\begin{array}{l}\text { Age }(y) \\
\operatorname{sex}\end{array}$ & $\begin{array}{l}\text { Duration of } \\
\text { asthma }(y)\end{array}$ & $\begin{array}{l}\text { Previous long term } \\
\text { prednisolone }\end{array}$ & $\begin{array}{l}\text { Short courses } \\
\text { of prednisolone } \\
\text { in preceding } \\
12 \text { months }\end{array}$ & $\begin{array}{l}\text { Daily dose } \\
B D P(\mu g)\end{array}$ & $\begin{array}{l}\text { Treatment } \\
\text { (months) } \\
\text { with this } \\
\text { dose }\end{array}$ \\
\hline 1 & $32, M$ & 3 & - & 1 & 1500 & 24 \\
\hline 2 & $35, \mathrm{M}$ & 31 & - & 0 & $2000 \star$ & 36 \\
\hline 3 & $42, F$ & 41 & - & 3 & 2000 & 48 \\
\hline 4 & $49, M$ & 35 & - & 1 & 2000 & 1 \\
\hline 5 & $39, \mathrm{~F}$ & 32 & - & 2 & 2500 & 1 \\
\hline 6 & $68, F$ & 40 & $\begin{array}{l}20 \mathrm{mg} \text { alternate days } 5 \mathrm{y} \text {; stopped } \\
22 \mathrm{y}\end{array}$ & 0 & 2000 & 18 \\
\hline 7 & $47, M$ & 19 & $\leqslant 7.5 \mathrm{mg}$ daily $17 \mathrm{y} ;$ stopped $1 \mathrm{y}$ & 0 & 2000 & 30 \\
\hline 8 & $62, M$ & 30 & $\begin{array}{l}17.5 \mathrm{mg} \text { alternate days } 13 \mathrm{y} \\
\text { stopped } 10 \mathrm{y}\end{array}$ & 1 & 1500 & 12 \\
\hline 9 & $57, \mathrm{~F}$ & 12 & $\leqslant 5 \mathrm{mg}$ daily $5 \mathrm{y} ;$ stopped $5 \mathrm{y}$ & 0 & 1500 & 54 \\
\hline 10 & $56, \mathrm{~F}$ & 21 & $\leqslant 5 \mathrm{mg}$ daily $8 \mathrm{y}$; stopped $3.6 \mathrm{y}$ & 1 & 1500 & 18 \\
\hline 11 & $19, F$ & 19 & - & 6 & 2000 & 13 \\
\hline 12 & $58, \mathrm{~F}$ & 23 & $\leqslant 10 \mathrm{mg}$ daily $13 \mathrm{y} ;$ stopped $5 \mathrm{y}$ & 0 & 1500 & 27 \\
\hline
\end{tabular}

$\star$ Plus $400 \mu \mathrm{g}$ intranasal.

diately before the intramuscular injection of tetracosactrin $250 \mu \mathrm{g}$. A second venous sample was taken 30 minutes later. A 24 hour urine sample was collected on a separate day. All patients had normal serum creatinine values. Serum and urine samples were assayed for free cortisol by radioimmunoassay (Amerlex, Amersham). Hypothalamo-pituitary-adrenal suppression was judged to be present if the results of at least two of the three tests were below the reference ranges established by our laboratory for healthy subjects: $0900 \mathrm{~h}$ serum cortisol concentration below $190 \mathrm{nmol} / \mathrm{l}$; a rise in serum cortisol in response to tetracosactrin of under $200 \mathrm{nmol} / \mathrm{l}$, or an achieved serum cortisol concentration of under $500 \mathrm{nmol} / 1 ; 24$ hour urine free cortisol excretion less than 80 nmol.

Of the 12 patients identified as having subnormal hypothalamo-pituitary-adrenal axis function, 11 were defined on the above criteria. The remaining patient (No 10) had persistently low 24 hour urine free cortisol excretion and her serum cortisol response to an insulin stress test was subnormal (a normal response for our laboratory is a rise in serum cortisol of more than $200 \mathrm{nmol} / 1$ from the baseline value to at least $500 \mathrm{nmol} / \mathrm{l}$ ). All patients stated that their 24 hour urine collection was complete and in five the collection was repeated and the abnormal results were confirmed.

The 12 patients were given a large volume spacer device (Volumatic, Allen and Hanbury) and instructed to inhale their beclomethasone dipropionate twice daily via the Volumatic spacer, each actuation of the aerosol canister to be followed by two inhalations from the spacer, with a breath hold of five seconds between inhalations. The total daily dose of drug was not changed. The tests of hypothalamo-pituitary-adrenal function were repeated after an interval of nine days to eight weeks in 10 patients; one patient (No 11) had to be given oral prednisolone because of poorly controlled asthma and the other (No 12) declined a repeat investigation. Nine of the 10 patients continued twice daily treatment and the other changed from four times to twice daily.

As the results were not normally distributed, a non-parametric statistical analysis (Wilcoxon signed rank test) was used.

\section{Results}

The initial findings in the hypothalamopituitary-adrenal function tests in all 12 patients and the results of repeat tests in 10 patients are shown in table 2 , with the median

Table 2 Effect of $750 \mathrm{ml}$ spacer device on hypothalamo-pituitary-adrenal axis function in asthmatic adults with suppression of this function taking high dose beclomethasone dipropionate

\begin{tabular}{|c|c|c|c|c|c|c|}
\hline \multirow[b]{2}{*}{$\begin{array}{l}\text { Patient } \\
\text { No }\end{array}$} & \multicolumn{3}{|c|}{ Metered dose inhaler } & \multicolumn{3}{|c|}{ Metered dose inhaler via $750 \mathrm{ml} \mathrm{spacer}$} \\
\hline & $\begin{array}{l}0900 \text { h serum } \\
\text { cortisol }(\mathrm{nmol} / \mathrm{l})\end{array}$ & $\begin{array}{l}\text { Serum cortisol } \\
\text { after tetracosactrin } \\
(\text { nmol/l) }\end{array}$ & $\begin{array}{l}24 \text { h urine } \\
\text { free cortisol } \\
\text { (nmol) }\end{array}$ & $\begin{array}{l}0900 \mathrm{~h} \text { serum } \\
\text { cortisol }(\mathrm{nmol} / \mathrm{l})\end{array}$ & $\begin{array}{l}\text { Serum cortisol } \\
\text { after tetracosactrin } \\
\text { (nmol/l) }\end{array}$ & $\begin{array}{l}24 \mathrm{~h} \text { urine } \\
\text { free cortisol } \\
(\text { nmol })\end{array}$ \\
\hline $\begin{array}{r}1 \\
2 \\
3 \\
4 \\
5 \\
6 \\
7 \\
8 \\
9 \\
10 \\
11 \\
12\end{array}$ & $\begin{array}{r}<30 \\
37 \\
43 \\
159 \\
94 \\
212 \\
199 \\
249 \\
193 \\
58 \\
262 \\
258\end{array}$ & $\begin{array}{l}284 \\
418 \\
117 \\
437 \\
256 \\
402 \\
385 \\
429 \\
426 \\
418^{\star} \\
370 \\
418\end{array}$ & $\begin{array}{r}59 \\
53 \\
<30 \\
99 \\
<30 \\
60 \\
56 \\
62 \\
<30 \\
60 \\
41 \\
37\end{array}$ & $\begin{array}{l}435 \\
451 \\
166 \\
427 \\
440 \\
166 \\
234 \\
396 \\
400 \\
202 \\
-\end{array}$ & $\begin{array}{l}627 \\
955 \\
259 \\
613 \\
825 \\
391 \\
450 \\
515 \\
642 \\
583 \star \\
-\end{array}$ & $\begin{array}{r}130 \\
270 \\
66 \\
124 \\
97 \\
48 \\
57 \\
73 \\
76 \\
93 \\
-\end{array}$ \\
\hline
\end{tabular}

^Maximum serum cortisol achieved during insulin induced hypoglycaemia. 
Figure 1 Influence of use of $750 \mathrm{ml} \mathrm{spacer}$ device on hypothalamo-pituitaryadrenal axis function in asthmatic adults taking high doses of beclomethasone dipropionate. MDI-metered dose inhaler;

Spacer-Volumatic $750 \mathrm{ml}$ large spacer device: $-\ldots-$ - lower limit of normal range.

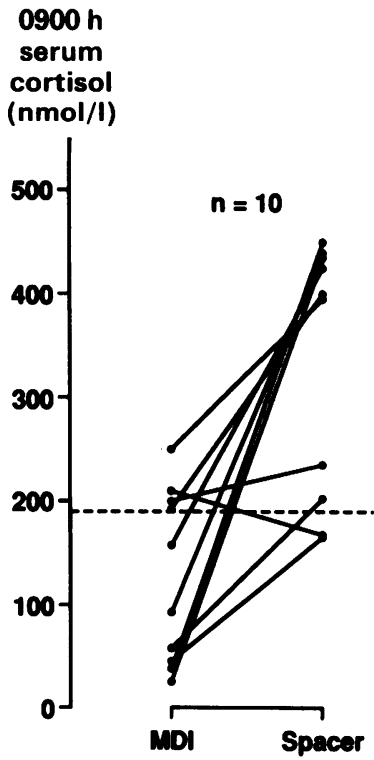

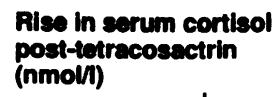

post-ietracosactrin

(nmol/h)

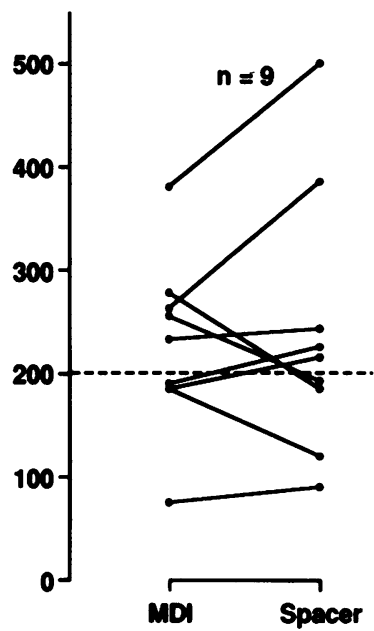

24 h urine
free cortisol
(nmol)

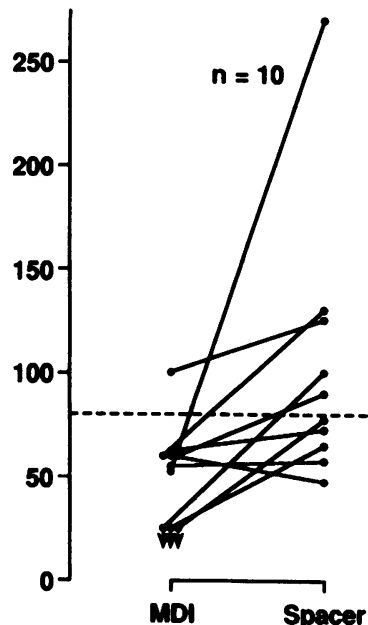

values and interquartile ranges in table 3 . In the 10 patients undergoing tests on two occasions the use of a spacing device in addition to a metered dose inhaler was associated with an increase in median $0900 \mathrm{~h}$ serum cortisol concentration from 126 to $398 \mathrm{nmol} / \mathrm{l}$, an increase in median serum cortisol concentration following tetracosactrin from 402 to $613 \mathrm{nmol} / 1$, and
Table 3 Changes in hypothalamo-pituitary-adrenal axis function in 10 asthmatic patients inhaling high dose beclomethasone dipropionate with and without a $750 \mathrm{ml}$ spacer device (medians with interquartile ranges)

\begin{tabular}{llclll}
\hline & $\begin{array}{l}\text { Metered dose inhaler } \\
(M D I)\end{array}$ & MDI via 750 ml spacer & $p^{\star}$ \\
\hline $0900 \mathrm{~h} \mathrm{cortisol}(\mathrm{nmol} / \mathrm{l})$ & 126 & $(41-202)$ & 398 & $(196-426)$ & $<0.01$ \\
$\begin{array}{c}\text { Post-tetracosactrin cortisol } \\
(\mathrm{nmol} / \mathrm{l})\end{array}$ & 402 & $(270-427)$ & 613 & $(420-733)$ & $<0.01$ \\
$\begin{array}{c}24 \mathrm{~h} \text { urine free cortisol } \\
(\mathrm{nmol})\end{array}$ & 54 & $(<30-60)$ & 84 & $(64-125)$ & $<0.01$ \\
\hline
\end{tabular}

«Wilcoxon signed rank test.

Figure 2 Influence of $750 \mathrm{ml}$ spacer on serum cortisol response to insulin induced hypoglycaemia in a patient inhaling $1500 \mu \mathrm{g}$ beclomethasone dipropionate daily. Three of these four patients had had long term

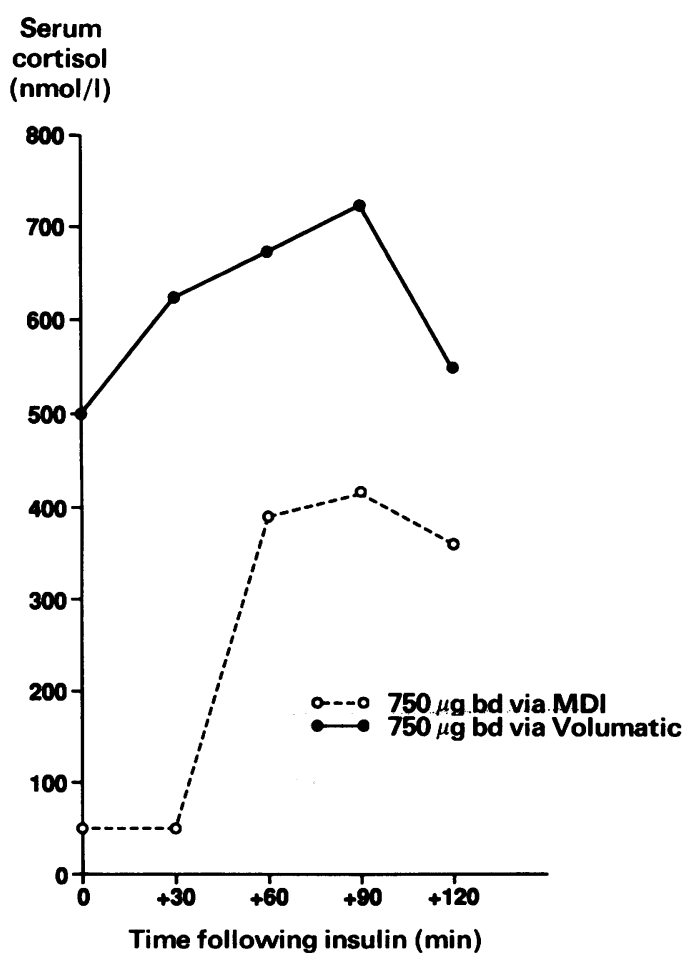

an increase in median 24 hour urine free cortisol from 54 to $84 \mathrm{nmol}$ ( $\mathrm{p}<0.01$ in each case; fig 1). There was no change in the rise in serum cortisol concentrations in response to tetracosactrin.

The insulin stress tests in patient 10 were started three hours after the last $750 \mu \mathrm{g}$ dose of beclomethasone dipropionate. The response to hypoglycaemia after inhalation of beclomethasone through the spacer for eight weeks is within normal limits (fig 2), despite her requirement for a short course of prednisolone (initial dose $25 \mathrm{mg}$ daily, reducing by $5 \mathrm{mg}$ daily to zero) three weeks before the second test.

Evidence of hypothalamo-pituitary-adrenal suppression persisted in only four of the 10 patients after they had been using the spacer. prednisolone previously. The repeat investigations were carried out at least six weeks after the four patients had started to use the spacer device. In contrast, two patients (Nos 3 and 4), who had never had long term oral prednisolone, showed substantial improvement in endocrine function within two weeks of using the spacer.

Asthmatic symptoms remained well controlled in six of the 10 patients while they were inhaling beclomethasone through the spacer. Three patients reported subjective improvement of asthma symptoms and a reduced requirement for inhaled bronchodilators; one patient needed a short course of prednisolone.

\section{Discussion}

The data reported in this study support the findings from previous studies that doses of 1500-2000 $\mu \mathrm{g}$ beclomethasone dipropionate daily, when inhaled from a conventional metered dose inhaler, may cause suppression of the hypothalamo-pituitary-adrenal axis. When the patients with impaired hypothalamopituitary-adrenal function inhaled the same dose of beclomethasone through a large volume spacer device for periods ranging from nine days to eight weeks there was an increase in $0900 \mathrm{~h}$ serum cortisol concentration, post- 
tetracosactrin serum cortisol, and 24 hour urine free cortisol excretion. Evidence of continuing suppression of the hypothalamo-pituitaryadrenal axis persisted in only four of the 10 patients. The reduction in systemic effect from the high dose inhaled corticosteroid was achieved without detrimental effect on control of asthma symptoms.

The greatest improvements in hypothalamopituitary-adrenal function were seen in four of the five patients who had never required long term oral prednisolone. None of the six who had required such treatment had previously undergone endocrine assessment and we cannot say how far oral, rather than inhaled, corticosteroids were responsible for their suppressed function. When five of these six, however, were reassessed after inhaling beclomethasone via the spacer, two showed substantial improvement, suggesting that high dose beclomethasone dipropionate was at least contributing to their hypothalamo-pituitaryadrenal axis suppression.

These results support the findings of Prahl and Jensen, who showed improved 24 hour urine free cortisol excretion in six of 10 children taking high dose beclomethasone dipropionate or budesonide after they had inhaled the steroid through a $750 \mathrm{ml}$ spacer for one month. ${ }^{7}$ Both studies, however, were uncontrolled. A randomised, controlled, double blind study is therefore being carried out.

It is not clear why large volume spacers should reduce hypothalamo-pituitary-adrenal suppression in patients taking high doses of inhaled corticosteroids. Radiolabelled aerosol studies show that when a metered dose inhaler is used without a spacer attachment less than $10 \%$ of the dose reaches the lungs, $80 \%$ being deposited in the oropharynx. ${ }^{9}$ With a $750 \mathrm{ml}$ spacer the fraction reaching the lungs is increased and oropharyngeal deposition is substantially reduced. ${ }^{10}$ Drugs deposited on the oropharynx have the potential to be absorbed directly across the mucosa or to be swallowed and absorbed from the stomach or intestine. Pharmacokinetic studies in healthy volunteers show that $90 \%$ of a swallowed dose of beclomethasone dipropionate is absorbed. ${ }^{11}$ The absence of substantial suppression of the hypothalamo-pituitary-adrenal axis with oral doses of beclomethasone below $4 \mathrm{mg}$ is attributed to the drug's high first pass hepatic metabolism. ${ }^{12}$ Variation between individuals in first pass metabolism could explain why some patients taking 1500-2000 $\mu \mathrm{g}$ beclomethasone dipropionate from a metered dose inhaler have hypothalamo-pituitary-adrenal axis suppression that is reduced by using a large volume spacer. Direct absorption of the drug from the oropharynx is an alternative explanation.

It has been suggested that the systemic effects of high dose inhaled beclomethasone dipropionate are due to absorption of the drug from the lungs. ${ }^{13}$ This absorption has been shown in animal studies, and human lungs are known to be capable of enzymatic hydrolysis of the drug to beclomethasone monopropionate, which also has glucocorticoid activity. ${ }^{12}$ If, however, absorption from the lung were responsible for hypothalamo-pituitary-adrenal axis suppression, the use of large volume spacers would be expected to increase the degree of suppression. This study and that of Prahl and Jensen ${ }^{7}$ provide evidence to the contrary.

Caution should be exercised in extrapolating results with beclomethasone dipropionate to budesonide. In a study of adults inhaling budesonide Toogood et al reported that morning serum cortisol concentrations were lower with doses of $1600 \mu \mathrm{g}$ daily inhaled via a $750 \mathrm{ml}$ spacer than with the same dose inhaled via a metered dose inhaler. ${ }^{8}$ Gordon et al, ${ }^{14}$ however, found that seven of nine adults with asthma were able to inhale $3.2 \mathrm{mg}$ budesonide daily via a $750 \mathrm{ml}$ spacer without appreciable suppression of the $0900 \mathrm{~h}$ plasma cortisol concentration. This dose would be expected to cause suppression if taken conventionally via a metered dose inhaler. Further investigation is needed to show whether using large volume spacers increases or decreases possible adverse systemic effects from high dose budesonide.

The results of this study suggest that patients with asthma taking $1500 \mu \mathrm{g}$ or more beclomethasone dipropionate daily should use large volume spacer devices to minimise potential adverse systemic effects.

1 Smith MJ, Hodson ME. High dose beclomethasone inhaler in the treatment of asthma. Lancet 1983;i:265-9.

2 Ebden P, Jenkins A, Houston G, Davies BH. Comparison of two high dose corticosteroid aerosol treatments, beclomethasone dipropionate $(1500 \mu \mathrm{g} /$ day $)$ and budesonide $(1600 \mu \mathrm{g} /$ day $)$, for chronic asthma. Thorax 1986;41:869-74.

3 Karalus NC, Harrison AC. Inhaled high dose beclomethasone in chronic asthma. NZ Med J 1987;100: 305-8.

4 Tarlo SM, Broder I, Davies GM, et al. Six month double blind, controlled trial of high dose, concentrated beclomethasone dipropionate in the treatment of severe chronic asthma. Chest 1988;93:998-1002.

5 Smith MJ, Hodson ME. Effects of long term high dose beclomethasone dipropionate on adrenal function. Thorax 1983;38:676-81.

6 Toogood JH, Jennings B, Baskerville J, Johansson S-A. Clinical use of spacer systems for corticosteroid inhalation therapy: a preliminary analysis. Eur J Respir Dis 1982;63 therapy: a preliminary

7 Prahl P, Jensen T. Decreased adreno-cortical suppression utilising the Nebuhaler for inhalation of steroid aerosols. Clin Allergy 1987;17:393-8.

8 Toogood JH, Baskerville J, Jennings B, et al. Use of spacers to facilitate inhaled corticosteroid treatment of asthma. Am Rev Respir Dis 1984;129:723-9.

9 Newman SP, Pavia D, Moren F, et al. Deposition of pressurised aerosols in the human respiratory tract. Thorax 1981;36:52-5.

10 Newman SP, Millar AB, Lennard-Jones TR, et al. Improvement of pressurised aerosol deposition with nebuhaler spacer device. Thorax 1984;39:935-41.

11 Martin LE, Tanner RJN, Clark TJH, Cochrane GM. Absorption and metabolism of orally administered beclomethasone dipropionate. Clin Pharmacol Ther 1974;15:267-75.

12 Martin LE, Harrison C, Tanner RJN. Metabolism of beclomethasone dipropionate by animals and man. Postgrad Med J 1975;51(suppl 4):11-20.

13 Harris DM. Clinical pharmacology of beclomethasone dipropionate. In: Mygind N, Clark TJH, eds. Topical steroid treatment for asthma and rhinitis. London: Baillière Tindall, 1980:34-7.

14 Gordon ACH, McDonald CF, Thomson A, et al. Dose of inhaled budesonide required to produce clinical suppression of plasma cortisol. Eur J Respir Dis 1987; 71:10-4. 